\title{
Analysis of Electrical Power Consumption in Container Crane of Container Terminal Surabaya
}

\author{
A.A. Masroeri ${ }^{1}$, Eddy Setyo Koenhardono ${ }^{2}$, Fathia Fauziah Asshanti ${ }^{3}$
}

\begin{abstract}
In electrification process, it is required an analysis of electrical power consumption that is needed in the operational of container crane. It aims to determine whether the amount of electrical power that is supplied by PLN can be optimally used in the operational of container crane to do loading and unloading activities. To perform the analysis of electrical power consumption, it is required various data and calculations. The required data are container crane specifications and other electrical equipment specifications, the amount of electrical power that is supplied by PLN, also the single line diagram from the electrical system at the port. While, the calculations that is needed to be performed are the calculation of electrical power load in motors and other electrical equipments, the calculation of nominal current and start current, the selection of cable and busbar, and the calculation of wiring diagram junction power. From the calculations that has been done, then the next step is to do the load flow analysis simulation by using software simulation, so an accurate and effective load flow analysis can be obtained to optimize loading and unloading activities at the port. The result of this research, it can be seen that container crane electrification will give advantages in both technical and economical for the company and for the ship, such as accelerate the loading and unloading time of containers and reduce idle time, especially in the operational of diesel generator.
\end{abstract}

Keywords-Container Crane, Electrification, Load Flow, Optimization

\section{INTRODUCTION}

$\mathrm{T}_{\mathrm{h}}$ he idea of green port is now being intensively

implemented by all port management of all ASEAN countries for the last five years, in both developed and developing ports. The application of the idea of green port at some ports in developed countries in Europe and Asia is a part of the effort to minimize the level of marine pollution, air pollution and other environmental damages that are caused by loading and unloading activities at the port.

Container Terminal Surabaya (TPS Company) is a company that handles the provision of container terminal facilities, both for domestic and international trade. TPS Company holds a very important role in economic growth and trade, especially for businessmen in the eastern part of Indonesia. Because of that, the demand of port services that is offered will increase. The increasing demands of port services will be certainly increasing port activities that will impact on increasing pollution around the port, such as air pollution and water pollution [1]. Therefore, it needs an effort to create a green port to overcome the environmental damages that are inflicted by various activities at the port.

In order to support the implementation of the idea of green port, Container Terminal Surabaya is now conducting container crane (CC) electrification on all units of container crane and some components and other main equipments. Electrification is a powering process on an equipment by using electricity. The benefits that

A.A. Masroeri, Departement of Marine Engineering, Institut Teknologi Sepuluh Nopember, Surabaya, 60111, Indonesia. E-mail: agoesrngkt@gmail.com

Eddy Setyo Koenhardono, Departement of Marine Engineering, Institut Teknologi Sepuluh Nopember, Surabaya, 60111, Indonesia. Email: koenhardono@gmail.com

Fathia Fauziah Asshanti, Departement of Marine Engineering, Institut Teknologi Sepuluh Nopember, Surabaya, 60111, Indonesia. Email: fathiafauziaha@gmail.com are obtained by doing electrification program of power supply of CC are: fuel cost efficiency, reduce environmental pollution, reduce maintenance frequency and reduce the cost for replacement engine parts.

In this research, an analysis for the requirement of electric power consumption that will be used in the operational of container crane will be conducted. There are three ways to determine the electric power consumption that will be used in this research, there are by using empirical formula, electrical load analysis and load flow simulation by using software simulation.

\section{METHOD}

\section{A. Loading and Unloading System at Port}

Loading and unloading system at port is all components or cargo handling equipments that are used to support loading and unloading cargo activity, from ship to port or otherwise. While, the loading and unloading activity at port is an activity of unloading goods from aboard of the ship by using crane and sling to the nearest land on the edge of the vessel, commonly known as dock, then from the dock by using a lorry, forklift or stroller, inserted and arranged into the nearest warehouse that is designated by the port officer [2]. The loading and unloading activity can be categorized into three kinds, there are:

a. Stevedoring

Stevedoring is an activity of unpacking goods from ship to dock/barge//truck or loading goods from dock/barge/truck into the ship by using a ship's tow or land's tow.

b. Cargo doring

Cargo doring is an activity of releasing goods from ropes/nets (tackle) at the dock and transporting goods from dock to warehouse/stacking field and then arranging in the warehouse/stacking field or otherwise.

b. Receiving/Delivery

Receiving/delivery is an activity of moving goods from a heap/hoarding place at the warehouse/stacking field and handing it over 
until it is arranged on the top of the vehicle at the warehouse/stacking field or otherwise.

The loading and unloading system is generally influenced by the type of goods or cargoes and also the type of packaging that is used. Ship's cargoes are grouped or differentiated according to some groupings appropriate with the type of shipping, the type of packaging and the natural characteristic of the cargo [3].

The types of ship's cargoes can be categorized as follows :

- General Cargo
- Bulk Cargo

- Liquid Cargo

- Live Stock Cargo

- Container Cargo

\section{A. Crane}

Crane is a lifting and transferring equipment for a material. Crane is used to lift load either in vertical or horizontal direction at the same time and raise or lower the load in a predetermined location [4]. The main parts of crane are shown in Figure 1 as follows.

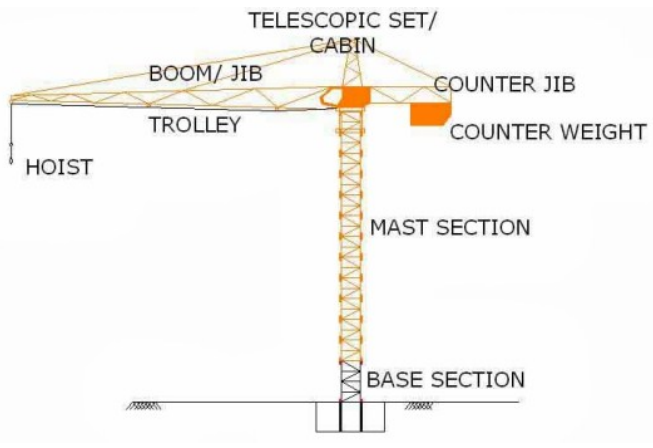

Figure 1. Main Parts of Crane

\section{B. Container Crane}

Container crane is a type of crane that is used for handling containers. The types of container crane that are commonly used for loading and unloading activity of containers at the port are :

a.Straddler Carrier
b.Container Spreader
c.Straddler Loader
d.Tanstrainer (Rubber Tyred Gantry Crane)
e.Side Loader
f. Container Forklift
g. Gantry Crane (Container Crane)

Container crane (CC) is a type of crane that installed permanently at the edge of the dock by using a rail, so it can move both to the left or right for loading and unloading containers in near or far range. In the container crane, there are several electrical components that operate. The electrical components are as follows :

\section{o Transformer}

Transformer is an electrical equipment that is used to convert the amount of alternating current (AC) voltage.

o Three-Phase Asynchronous Motor

Three-phase asynchronous motor is an electrical equipment that is used to convert three-phase alternating current source into mechanical energy.

o Direct Current Motor

Direct current motor (DC motor) is an electrical equipment that is used to convert direct current source (DC current) into mechanical energy.

o Three-Phase Controlled Rectifier

A rectifier series is a series that can convert AC voltage into $\mathrm{DC}$ voltage. One of the main component in a three-phase controlled rectifier is thyristor or commonly called as SCR (Silicon Controlled Rectifier) as a rectifier component that can control DC voltage output [5]. A rectifier can be distinguished into full-wave controlled rectifier and half-wave controlled rectifier.

\section{The Electrical System of Container Crane}

The electrical system in the operational of container crane is shown in Figure 2. In the operational of container crane that is shown in Figure 2, there are several equipments that operate, there are transformer, three-phase asynchronous motor, direct current motor (DC motor) and three-phase controlled rectifier.

The electrical system of container crane starts from a power source that will supply electrical energy. The power plant used are diesel generators or National Electric Company (PLN) source. After that, then the electricity is flowed into main transformer and auxiliary transformer. Main transformer and auxiliary transformer will lower the voltage from the source. The output voltage from main transformer will be flowed into motors and equipments in the container crane, such as hoist drive, gantry drive, boom drive and trolley drive, while the output voltage from auxiliary transformer will be flowed into the auxiliary power. 


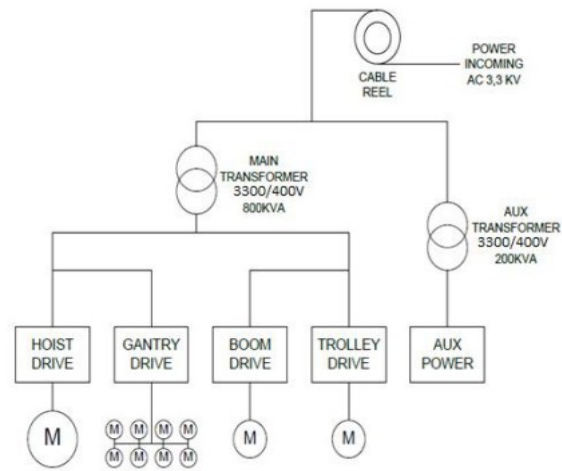

Figure 2. The Electrical System of Container Crane

E. Layout and Container Crane Electrification Planning The container crane electrification planning that is now being held by Container Terminal Surabaya has been occurred since October 2016 and it was planned to be done in 2017.
Container Terminal Surabaya has 16 container cranes, consist of 14 container cranes that operate in International quay and 2 container cranes that operate in Domestic quay. The layout of the location of electrical substations from PLN to TPS Company is shown in Figure 3.

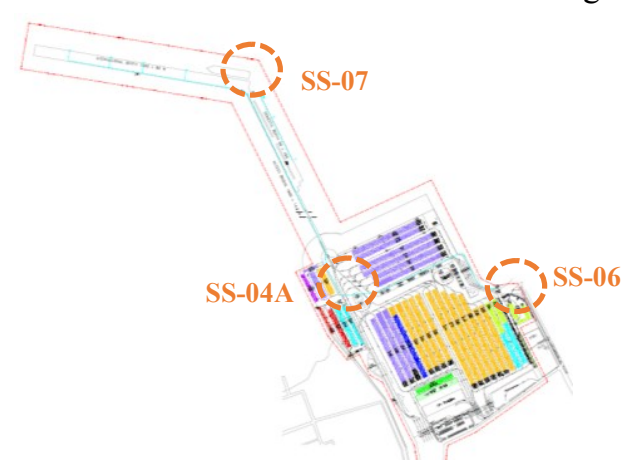

Figure 3. The Layout of Electrical Substations Location

\section{F. Load Flow Analysis}

Load flow analysis is an analysis that is used to find out the characteristics of load flow in the form of load variations and transmission losses effect in the load flow. To do the load flow analysis, it is needed a single line diagram, which is a simplified notation for a three-phase power electricity system.

In this research, the software simulation will be used to analyze load flow that works on all container crane that will be performed electrification in TPS Company. From the result of the simulation that has been obtained, we will get the value of active and reactive power and also the value of voltage percentage on every equipment that works in the container crane.

\section{G. Analysis of Electrical Power Consumption}

In this research, the analysis of electrical power consumption of container crane and the simulation of load flow will be conducted to determined the amount of electricity power capacity that is needed in the operational of container crane in electrification program. The load flow analysis, includes the calculation of total load on every equipment, the calculation of wiring diagram junction power, the calculation of start current and total current and also the selection of cables and busbars. Furthermore, the simulation of load flow will be conducted by using software simulation.
The next step is to determine the criteria of loading and unloading optimization that is obtained from the result of the analysis of load flow simulation and the references comparison from technicians and container crane operators. To support the research, the case study is conducted at Container Terminal Surabaya (TPS Company). 
TABLE 1 .

The CALCUlation of Total Electrical LoAD ON ALL

\begin{tabular}{|c|c|c|c|c|c|}
\hline No. & Specification & $\begin{array}{c}\text { KONE } \\
\text { Total KW }\end{array}$ & $\begin{array}{l}\text { HITACHI } \\
\text { Total KW }\end{array}$ & $\begin{array}{c}\text { IMPSA } \\
\text { Total KW }\end{array}$ & $\begin{array}{c}\text { IHI } \\
\text { Total KW } \\
\end{array}$ \\
\hline 1 & Motor Hoist & 4680 & 420 & 2320 & 700 \\
\hline 2 & Motor Gantry & 2664 & 120 & 608 & 240 \\
\hline 3 & Motor Trolley & 1044 & 60 & 560 & 194 \\
\hline 4 & Motor Boom & 726 & 65 & 280 & 90 \\
\hline 5 & Trim-List Motor & 234 & 15 & 88 & 14 \\
\hline 6 & Main Hoist Brake & 36 & 4 & 32 & 8 \\
\hline 7 & Trolley Brake & 27 & 4 & 48 & 8 \\
\hline 8 & Gantry Brake & 72 & 6 & 32 & 24 \\
\hline 9 & Wheel Brake & 180 & 20 & 80 & 40 \\
\hline 10 & Boom Hoist Brake & 27 & 3 & 12 & 6 \\
\hline 11 & $\begin{array}{c}\text { Emergency Brake for } \\
\text { Boom Drum }\end{array}$ & 36 & 4 & 60 & 8 \\
\hline 12 & Spreader & 67.5 & 7.5 & 30 & 15 \\
\hline 13 & Fuel Pump & 45 & 5 & 20 & 10 \\
\hline 14 & Man Lift & 90 & 10 & 40 & 20 \\
\hline 15 & Air Conditioning & 234 & 6 & 40 & 4 \\
\hline 16 & Lighting & 36 & 12 & 60 & 24 \\
\hline 17 & Auxiliary & 27 & 20 & 80 & 40 \\
\hline \multicolumn{6}{|c|}{$\begin{array}{c}781.5 \\
16950 \\
\mathbf{~ K W}\end{array}$} \\
\hline
\end{tabular}

\section{B. The Calculation Wiring Diagram Junction Power}

Wiring diagram junction power is a scheme to find out how much the amount of electrical power on each component, and also to find out how much the amount of current that flows on each component [4].

To do the calculation of wiring diagram junction power, it needs several calculations, such as :

○ The calculation of nominal current and start current on electric motors.

○ The calculation of busbar

\section{Load Flow Analysis}

To do the load flow analysis by using software simulation, it is needed a Single Line Diagram of the electricity system at TPS Company. The single line diagram of the electrical system in Container Terminal Surabaya is shown in Figure 4

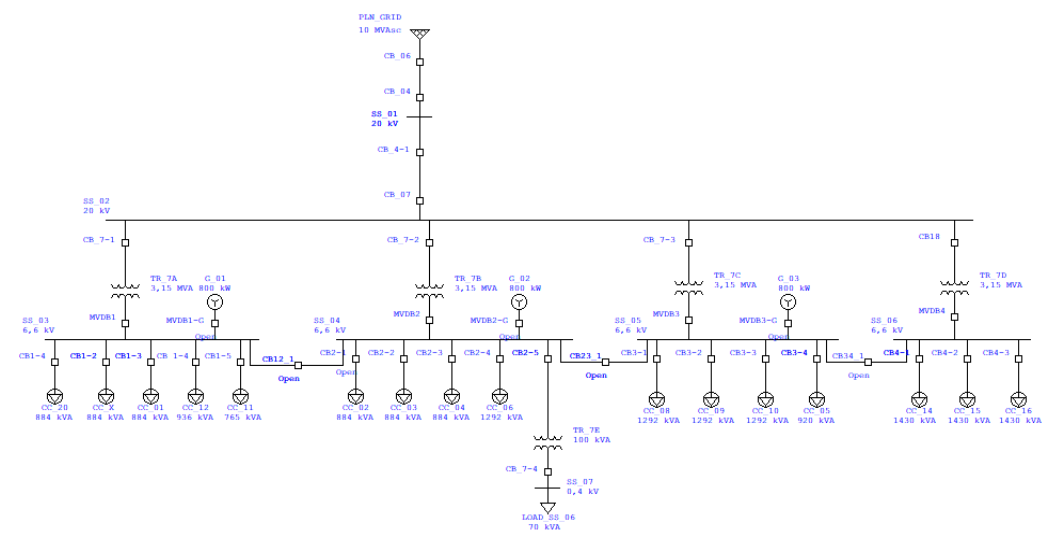

Figure 4. Single Line Diagram of PT. Terminal Petikemas Surabaya

\section{RESULTS AND DISCUSSION}

\section{A. The Calculation of Electrical Power Consumption of} Container Crane

To calculate the amount of electrical power consumption that is required in the operational of container crane, it is required the calculation of electrical power load for every electrical motors and other electrical equipments that operate in the container crane. Based on the data that has been obtained, so the total amount of the electrical power consumption is shown in Table 1.
After all the equipments in the single line diagram has been filled completely, then the next step is running load flow analysis in software simulation. In this research, some scenarios of load flow in the operational of container crane will be carried out. The scenarios are:

- Scenario 1: all container cranes (CC) are operating.

- Scenario 2: CC9 \& CC10; CC6 \& CC4; dan $\mathrm{CC} 11 \& \mathrm{CC} 12$ are operating. 
- Scenario 3 : CC8, CC9 \& CC10; dan CC3, CC4 \& CC6 are operating.

- Scenario 4: CC8, CC9 \& CC10; CC4 \& CC6, CC20; dan $\mathrm{CC} 14$ \& $\mathrm{CC} 15$ are operating.

- Scenario 5 : CC8, CC9 \& CC10; CC3, CC4 \& CC6; $\mathrm{CC} 11$ \& $\mathrm{CC} 12$; dan $\mathrm{CC} 15$ \& $\mathrm{CC} 16$ are operating.

In the running of load flow analysis, there are 2 parameter initiation to indicate a system or an equipment is in abnormal condition. These parameters are critical condition that is marked with red color, and marginal condition that is marked with pink color. The critical condition is a standard or a limit of an equipment or system can be indicated in critical condition, where if it is exceeded, it will cause damage or failure operation on the component. The marginal condition is a standard or limit of an equipment almost enter the critical limit range so it is necessary to be considered of a repair mechanism [6].

The result of load flow simulation in some scenario of the operational of CC are shown as follows :

1. The result of the simulation of Scenario 1 in Figure 5, it can be seen that some transformers and busbars such as TR 7A, TR 7C, TR_7D, SS_03, SS_04, SS_05, SS_ 06 and SS_07 are in critical condition. The operating percentage of these components are TR_7A $134.8 \%$, TR_7C $106.4 \%$, TR_7D $132.2 \%$, SS_03 92.9\%, SS_04 $93.5 \%$, SS $0591.9 \%$, SS 06 93\% and SS 07 $92.7 \%$. To overcome the critical condition equipment, the solution is by doing shift or scheduling on $\mathrm{CC}$ which operates in one day, so all $\mathrm{CC}$ do not operate at the same time which may cause critical condition.
2. The result of the simulation of Scenario 2 in Figure 6, it can be seen that some busbars, such as SS_03, SS_04, SS_05 and SS_07 are in marginal condition. The operating percentage of these components are SS_03 97.4\%, SS_04 $96.8 \%$, SS $0596.1 \%$ and SS $0795.9 \%$. To overcome with this condition, the solution that can be done is to do jumper or connecting the busbar that is in marginal condition with the other busbar that is in normal condition.

3. The result of the simulation of Scenario 3 in Figure 7, it can be seen that some busbars, such as SS_05 and SS_07 are in critical condition, while busbar SS_04 is in marginal condition. The operating percentage of these components are SS_05 94.1\%, SS_07 94.7\% and SS_04 95.5\%. To overcome with this condition, the solution that can be done is to do jumper or connecting the busbar that is in marginal condition with the other busbar that is in normal condition.

4. The result of the simulation of Scenario 4 in Figure 8 , it can be seen that some busbars, such as SS 05 is in critical condition, while busbar SS_04, SS_06 and SS_07 are in marginal condition. The operating percentage of these components are SS_05 94.8\%, SS_04 97.2\%, SS_06 96.2\% and SS_07 96.3\%. To overcome with this condition, the solution that can be done is to do jumper or connecting the busbar that is in marginal condition with the other busbar that is in normal condition.

5. The result of the simulation of Scenario 5 in Figure 9 , it can be seen that some busbars, such as SS_05 is in critical condition, while busbars SS_03, SS_04, SS_06 and SS_07 are in marginal condition. The operating percentage of these components are SS_05 94.8\%, SS_03 $97.8 \%$, SS_04 96\%, SS_06 $96.2 \%$ and SS_07 $95.1 \%$. To overcome with this condition, the solution that can be done is to do jumper or connecting the busbar that is in marginal condition with the other busbar that is in normal condition.

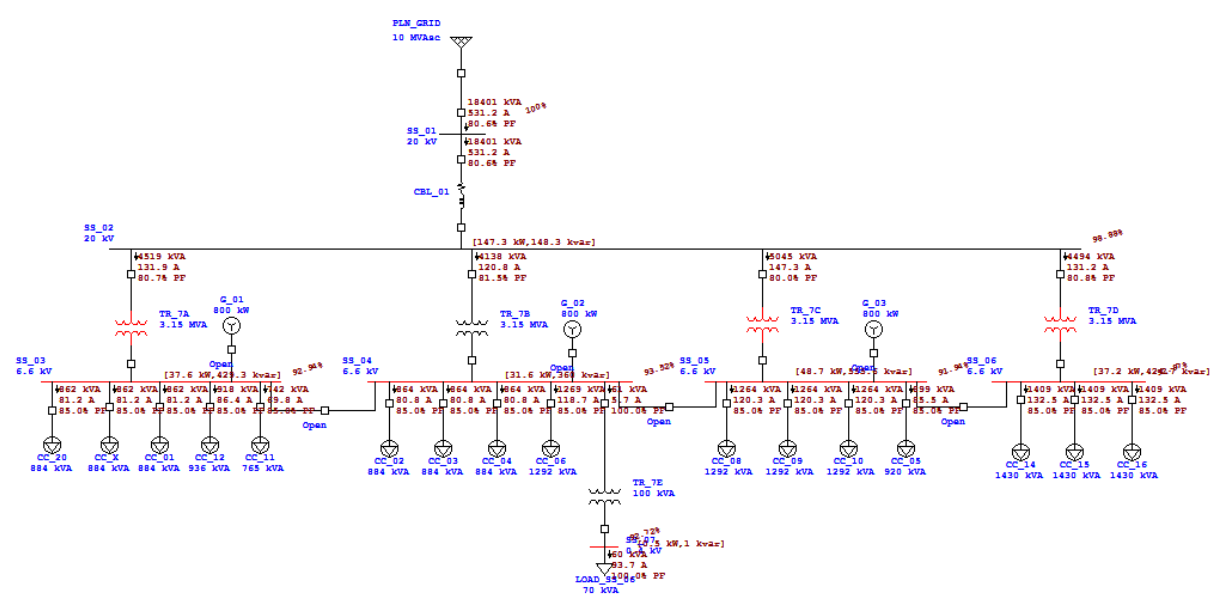

Figure 5. Load Flow Analysis : Scenario 1 


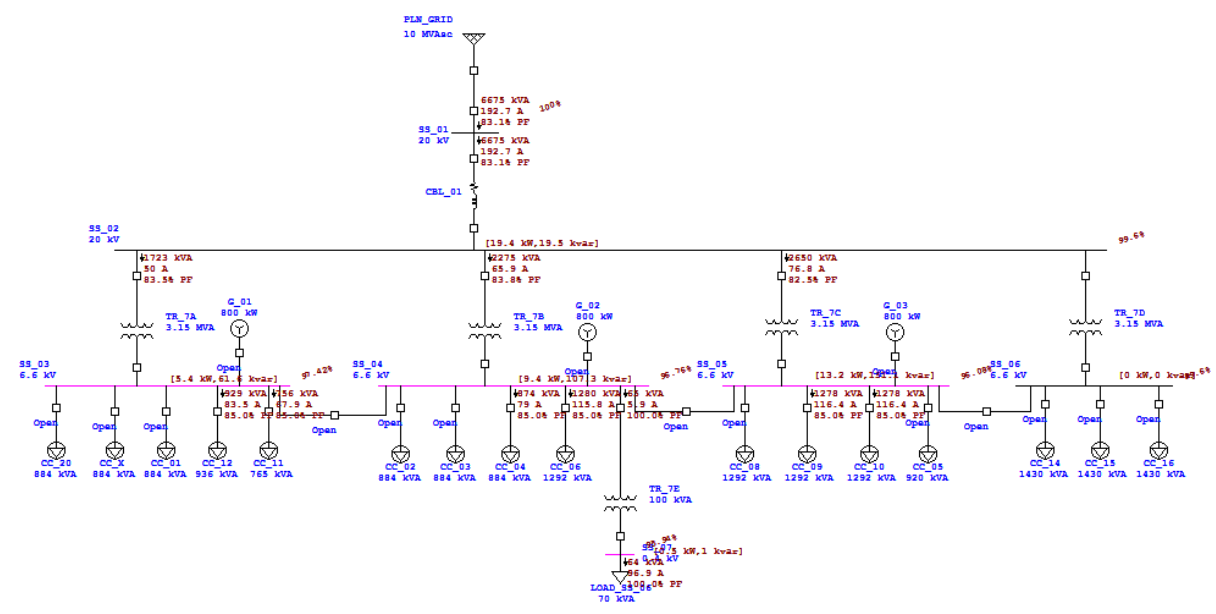

Figure 6. Load Flow Analysis : Scenario 2

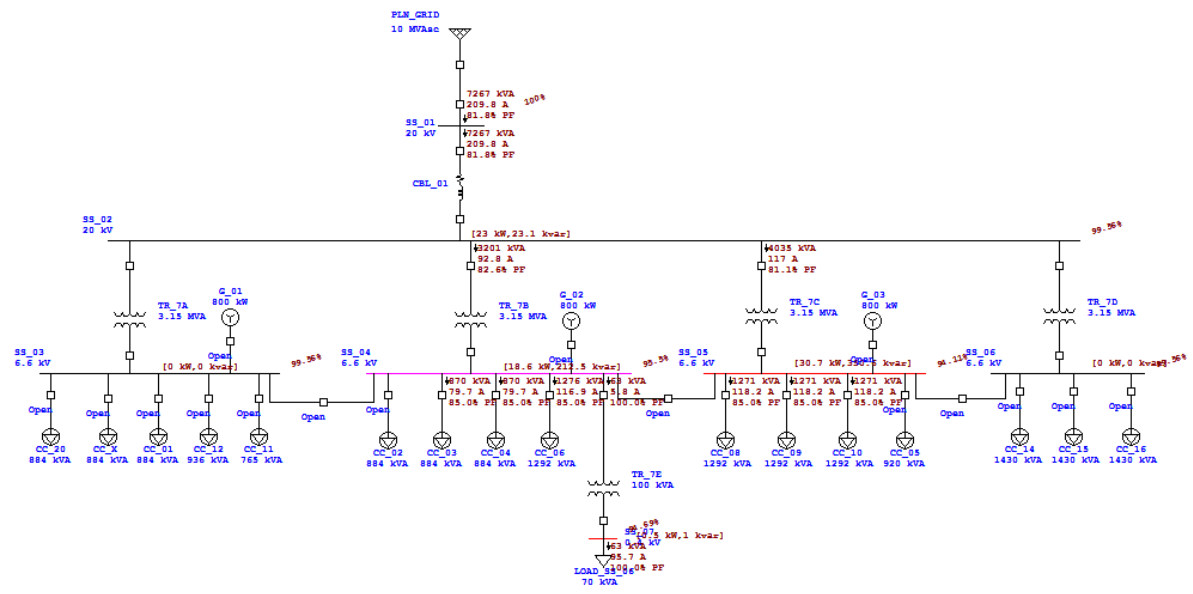

Figure 7. Load Flow Analysis : Scenario 3

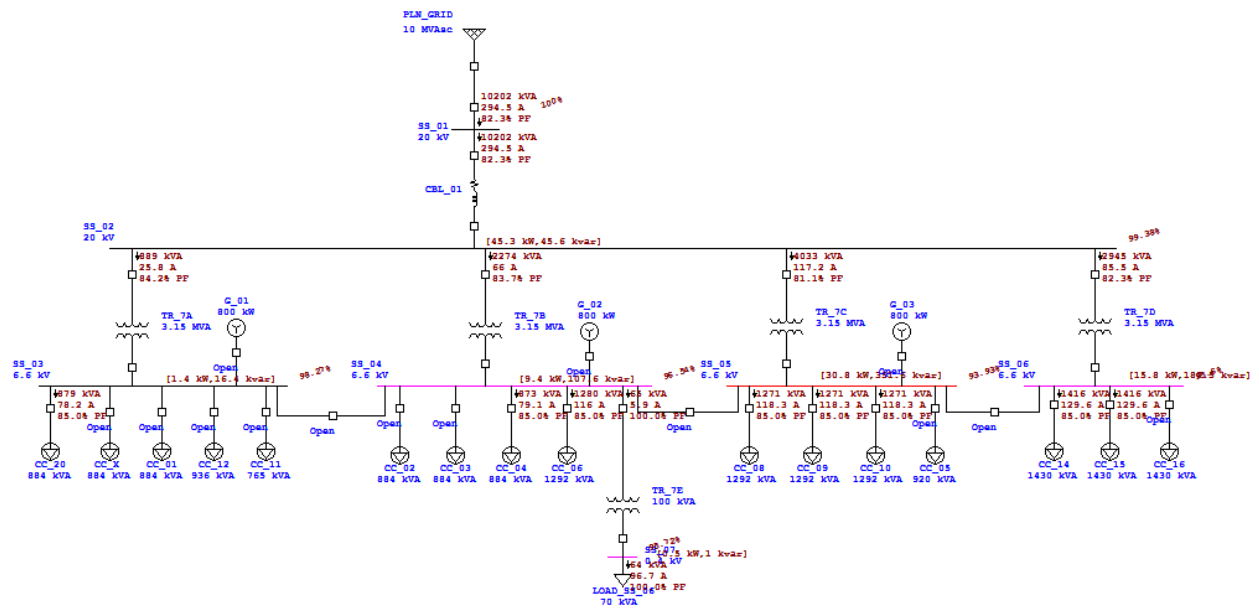

Figure 8. Load Flow Analysis : Scenario 4 


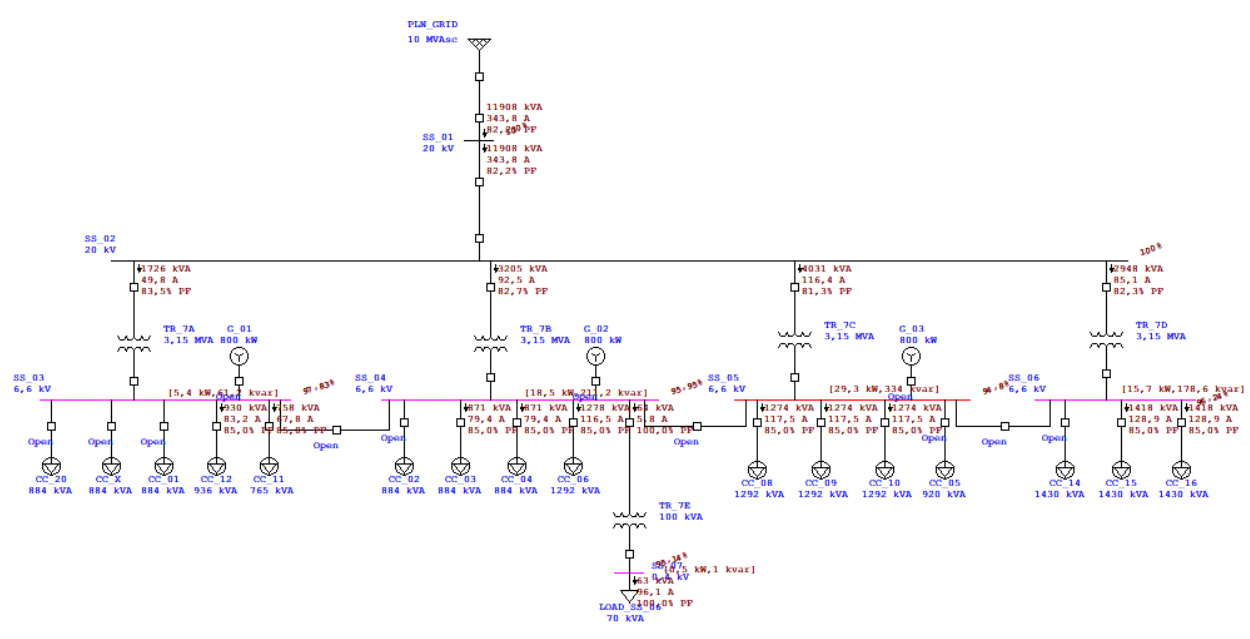

Figure 9. Load Flow Analysis : Scenario 5

\section{Loading and Unloading Optimization}

To measure the optimization of the operational of container terminal, there are several indicators that are related to the service of the ship at the dock. One of the indicator is service time that is showed in Figure 10. The service time consists of :

a. Berthing time

Berthing time (BT) is the total time that is used by the ship during mooring. Berthing time consists of berth working time and not operation time.

b. Berth Working Time

Berth working time is a time planned to do loading and unloading activity, that consists of effective time and idle time.

c. Not Operation Time

Not operation time is a time planned to not working (not doing loading and unloading activity) such as rest period.

d. Effective Time

Effective time is a time used to do loading and unloading activity effectively.

e. Idle Time

Idle time is a time that is not used to do loading

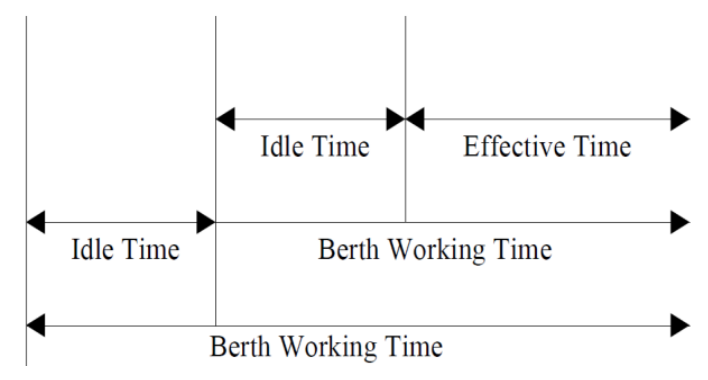

Figure 10. Service Time at the Dock

Based on the result of interviews and discussions with technicians and container crane operators at Container Terminal Surabaya, the result of the optimization analysis of loading and unloading from electrification program are as follows :

1. Electrification gives faster loading and unloading containers. Previously, the time that is used to do loading and unloading for container ship with LOA $\geq 180 \mathrm{~m}$ and containers $1500-1800$ boxes is served within 2-3 days, but now it can be served up to 1-1.5 days.

2. Electrification reduces idle time on diesel generators, where generators can not operate continuously to supply electrical power (it needs time to shut it down before it starts again). This will shorten berthing time, so the time service will be faster.

3. The faster service time will give advantages in economical, both for the company or the ship.

\section{CONCLUSION}

From the research that has been done, including the calculations and simulations, some conclusions can be obtained as follows :

1. The total load of electrical power from the operational of all container cranes is $16950 \mathrm{KW}$, where the total load of KONE Crane is $1033.5 \mathrm{KW}$, HITACHI Crane is $781.5 \mathrm{KW}$, IMPSA Crane is $4390 \mathrm{KW}$ and IHI Crane is $1445 \mathrm{KW}$.

2. The load flow simulation of the electrical power in some scenarios of loading and unloading by using software simulation can be concluded as follows :

- The operational of all CC simultaneously will result critical condition in some electrical components such as busbars and transformers. Therefore, the operational of all CC simultaneously should be avoided.

- Based on the result from some simulations of the operational of $\mathrm{CC}$, it can be concluded that 
5972, eISSN: 2548-1479)

the most recommended operational scenario is Scenario 2 compared to the other operational scenarios.

3. The implementation of electrification program affects the service time of containers at the dock, where the service time of containers become faster, so it gives technical and economical benefits for both the company and the ship.

\section{REFERENCES}

[1] Hutagalung, B. R. (2004). Dampak Aktivitas Pelabuhan dan Sebaran Pencemaran Lingkungan Pelabuhan Tanjung Emas Semarang dan Kawasan Sekitarnya. Semarang: Universitas Diponegoro.

[2] Sasono, H. B. (2012). Manajemen Pelabuhan dan Realisasi Ekspor Impor. Yogyakarta: Andi Offset.

[3] Arwinas, D. (1999). Petunjuk Penanganan Kapal dan Barang di Pelabuhan, PT (Persero) Pelabuhan Indonesia II. Jakarta.

[4] Iqbal, M. (2011). Analisa Kapasitas Daya Listrik Container Crane untuk Optimalisasi Proses Bongkar Muat. Surabaya: Institut Teknologi Sepuluh Nopember.

[5] Saragi, S. H. (2012). Sistem Operasi Container Crane (CC) di Container Terminal Semarang. Semarang: Universitas Diponegoro.

[6] (2017). Simulasi Load Flow Analysis ETAP 12. Surabaya: Power System Simulation Laboratory. 